\title{
Impact of hot fluid advection on hydrocarbon gas production and seepage in mud volcano sediments of thick Cenozoic deltas
}

\author{
Marianne Nuzzo ${ }^{\mathrm{a}, *, 1}$, Marcus Elvert ${ }^{\mathrm{b}}$, Mark Schmidt ${ }^{\mathrm{a}}$, Florian Scholz ${ }^{\mathrm{a}}$, Anja Reitz ${ }^{\mathrm{a}}$, \\ Kai-Uwe Hinrichs ${ }^{\mathrm{b}}$, Christian Hensen ${ }^{\mathrm{a}}$ \\ a GEOMAR $\mid$ Helmholtz Centre for Ocean Research Kiel, Wischhofstraße 1-3, D-24148 Kiel, Germany \\ ${ }^{\mathrm{b}}$ Organic Geochemistry Group, Department of Geosciences and MARUM-Centre for Marine Environmental Sciences, University of Bremen, \\ Leobener Str., D-28359 Bremen, Germany
}

\section{A R T I C L E I N F O}

\section{Article history:}

Received 17 June 2011

Received in revised form 30 April 2012

Accepted 7 May 2012

Editor: G. Henderson

\section{Keywords:}

submarine mud volcano

high sedimentation rate Cenozoic deltas petroleum degradation

anaerobic oxidation of methane

lipid biomarkers and compound specific

isotope analysis

multivariate statistical analyses

\begin{abstract}
A B S T R A C T
Hydrocarbon seeps are ubiquitous at gas-prone Cenozoic deltas such as the Nile Deep Sea Fan (NDSF ${ }^{2}$ ) where seepage into the bottom water has been observed at several mud volcanoes $\left(\mathrm{MVs}^{3}\right)$ including North Alex MV $\left(\mathrm{NAMV}^{4}\right)$. Here we investigated the sources of hydrocarbon gases and sedimentary organic matter together with biomarkers of microbial activity at four locations of NAMV to constrain how venting at the seafloor relates to the generation of hydrocarbon gases in deeper sediments. At the centre, high upward flux of hot $\left(70^{\circ} \mathrm{C}\right)$ hydrocarbon-rich fluids is indicated by an absence of biomarkers of Anaerobic Oxidation of Methane (AOM) and nearly constant methane $\left(\mathrm{CH}_{4}\right)$ concentration depthprofile. The presence of lipids of incompatible thermal maturities points to mixing between earlymature petroleum and immature organic matter, indicating that shallow mud has been mobilized by the influx of deep-sourced hydrocarbon-rich fluids. Methane is enriched in the heavier isotopes, with values of $\delta^{13} \mathrm{C} \sim-46.6 \%$ VPDB and $\delta \mathrm{D} \sim-228 \%$ VSMOW, and is associated with high amounts of heavier homologues $\left(\mathrm{C}_{2+}\right)$ suggesting a co-genetic origin with the petroleum.

On the contrary at the periphery, a lower but sustained $\mathrm{CH}_{4}$ flux is indicated by deeper sulphatemethane transition zones and the presence of ${ }^{13} \mathrm{C}$-depleted biomarkers of $\mathrm{AOM}$, consistent with predominantly immature organic matter. Values of $\delta^{13} \mathrm{C}^{-} \mathrm{CH}_{4} \sim-60 \%$ VPDB and decreased concentrations of ${ }^{13} \mathrm{C}$-enriched $\mathrm{C}_{2}$ are typical of mixed microbial $\mathrm{CH}_{4}$ and biodegraded thermogenic gas from Plio-Pleistocene reservoirs of the region. The maturity of gas condensate migrated from pre-Miocene sources into Miocene reservoirs of the Western NDSF is higher than that of the gas vented at the centre of NAMV, supporting the hypothesis that it is rather released from the degradation of oil in Neogene reservoirs. Combined with the finding of hot pore water and petroleum at the centre, our results suggest that clay mineral dehydration of Neogene sediments, which takes place posterior to reservoir filling, may contribute to intense gas generation at high sedimentation rate deltas.
\end{abstract}

(c) 2012 Elsevier B.V. All rights reserved.

\section{Introduction}

Seepage of fluids and hydrocarbon gases from buried sediments at continental margins leads to the formation of a variety of features ranging from depressions, or pockmarks (Hovland and

\footnotetext{
* Corresponding author. Tel.: +351210924 600x4051; fax: +351214719018.

E-mail address: marianne.nuzzo@lneg.pt (M. Nuzzo).

1 Present address: Laboratório Nacional de Energia e Geologia, Unidade de Geologia Marinha, Estrada da Portela, Bairro do Zambujal, Apartado 7586, Alfragide, 2610-143 Amadora, Portugal and Instituto Dom Luiz, Faculdade de Ciências da Universidade de Lisboa, Campo Grande, Edifício C8, Piso 3, 1749-016 Lisboa, Portugal.

2 NDSF:Nile Deep Sea Fan.

${ }^{3} \mathrm{MV}$ : mud volcano.

${ }^{4}$ NAMV: North Alex mud volcano.
}

Judd, 1988), to positive structures such as mud volcanoes (MVs; Dimitrov, 2002) at the seafloor. At MVs, a mixture of hydrocarbon gases, water, petroleum and mud is transported from depth through a vertical feeder channel to the seafloor (Ivanov et al., 1998). The MVs develop at faults or fault intersections as a result of strong lateral or vertical compression in a range of settings that include high sedimentation rate Tertiary deep-sea fans such as the Mississippi (Roberts and Carney, 1997) or the Nile (Loncke et al., 2004) delta. At MVs, the buoyant ascension of fluidized mud is sustained by pore space pressurization (Brown, 1990). Pore space overpressure is provoked by the release of large amounts of water and hydrocarbon gases during the diagenesis of buried sediments at temperatures typically higher than $60{ }^{\circ} \mathrm{C}$ (Dählmann and de Lange, 2003; Claypool and Kvenvolden, 1983). The extruded sediment, called mud breccia, consists of a clayey matrix 